\title{
STRESS ANALYSIS OF R.C.C. DESIGNED SHEAR WALL IN A BUILDING FRAME SUBJ ECTED TO WIND LOADS
}

\author{
Mohit Sheode ${ }^{1}$
}

Abstract- Stress analysis is one of the ways to determine the strength of solids. Stress analysis can be based on any of the several theories of failure as proposed by great researchers like Rankine, St. Venant, Guest, Mises Henky, Haigh and Mohr. There is no great uniformity of opinion in determining elastic failure due to complex nature of failure. This paper is an attempt to study the stresses in a shear wall that is designed as per IS: 456:2000 using STAAD.Pro Software

Keywords - Wind Loads, Shear Wall, Stresses, Design wind speed, Storey drift

\section{INTRODUCTION}

Shear wall is one which is resistant to horizontal loading. The shear wall can be part of a service core or a stairwell, it may also serve as partition between residential apartments. They are usually continuous down to the base to which they are rigidly supported. Shear wall may be planar, but are often of L, T or I shape. In this paper a building of $15 \mathrm{~m}$. height is used with a symmetrical plan. Analysis is done using STAAD.Pro software. Wind loads to check the effect on building as well as shear wall are also applied. Result is collected in terms of stresses in shear wall panels. Also, maximum nodal displacement, maximum shear force, maximum bending moment, maximum axial force, maximum storey drift are noted for the building frame elements. Some of the allied literature on the topic are as follows:

J. Lombard et al. [1] did a study on seismic strengthening and repair of reinforced concrete shear walls, repair and strengthening of the shear walls were done using externally bonded carbon fiber tow sheets. Their paper concluded that the carbon fiber sheets can be used effectively to recover the initial elastic stiffness and to increase the yield load. The anchoring system is also an important element of carbon fiber strengthening system. A. E. Cardenas et al. [2] did a study on design provisions for shear walls, they discussed the special provisions for walls, of the ACI building code (ACI 318-71). They concluded that flexural strength, as well as shear strength, must be considered in an evaluation of the load-carrying capacity of any shear wall. A. AstanehAsl [3] did a study on seismic behavior and design of steel shear walls, response modification factors, system over-strength factor and deflection amplification factor were suggested for possible inclusion in design codes such as IBC and SEAOC Blue Book. H. Hiraishi [4] did the evaluation of shear and flexural deformations of flexural type shear walls. The findings were that

\footnotetext{
${ }^{1}$ Department of Civil and Environmental Engineering NITTTR, Bhopal, Madhya Pradesh, India
} 
flexural and shear deformations are estimated with excellent accuracy by using the rotation center at the base of the column under compression.

The rest of the paper is organized as follows. Structural modelling and analysis are explained in section II. Result and discussion are presented in section III. Concluding remarks are given in section IV.

\section{STRUCTURAL MODELLING AND ANALYSIS}

A. $\quad$ Case details -

A five-storey 3D building frame with $3 \mathrm{~m}$. each storey level is taken. The building has shear wall formulated with alike panels. The shear wall is designed as per IS: 456: 2000. Shear walls are located at left and right faces of building frame. The shear wall at both faces has 5 panels each of $3 \mathrm{~m}$. height and $2 \mathrm{~m}$. width.

\section{B. $\quad$ Material and Geometrical Properties -}

Following material properties have been considered in modelling:

Specific weight of RCC: $25 \mathrm{kN} / \mathrm{m}^{3}$

Size of Columns (Const.) $=550 \times 300 \mathrm{~mm}$.

Size of beams $($ Const. $)=350 \times 200 \mathrm{~mm}$.

Thickness of Shear wall $=250 \mathrm{~mm}$.

Concrete cover for shear wall (as per design) $=25 \mathrm{~mm}$.

Yield strength for reinforcement of shear wall $\left(F_{y}\right)=415 \mathrm{~N} / \mathrm{mm}^{2}$

C. $\quad$ Loading conditions -

1. Dead Load:

Self-weight of slab $=2 \mathrm{kN} / \mathrm{m}^{2}$.

2. Live Loads:

Live load as per IS 875 (Part 2):1987

Loading Class III (assumed)

Live Load on typical floors $=3 \mathrm{kN} / \mathrm{m}^{2}$

3. Wind Loads:

As per IS: 875 (Part III): 1987

For calculation of design wind speed and design wind pressure, parameters considered as per above code are as follows for all cases irrespective of any group.

i) Wind Zone: V

ii) Terrain Category: 4

iii) Design wind speed $\left(\mathrm{V}_{\mathrm{z}}\right)$

$\mathrm{V}_{\mathrm{Z}}=\mathrm{V}_{\mathrm{b}} \times \mathrm{K}_{1} \times \mathrm{K}_{2} \times \mathrm{K}_{3}$

$\mathrm{V}_{\mathrm{b}}($ Zone $\mathrm{V})=50 \mathrm{~m} / \mathrm{s}$

$\mathrm{K}_{1}$ (Important building) $=1.08$

$\mathrm{K}_{3}$ (Plain ground) $=1.0$

$\mathrm{K}_{2}$ (at $12 \mathrm{~m}$. and $15 \mathrm{~m}$.) $=0.8$

Design wind pressure $\left(\mathrm{P}_{\mathrm{z}}\right)=1.119 \mathrm{kN} / \mathrm{m}^{2}$

D. Model details -

STAAD.Pro software is used for structural modeling and analysis. The plan of $66 \mathrm{~m}^{2}$ $(11 \mathrm{~m} \times 6 \mathrm{~m})$ shown in Figure 1, is considered. Model of building frame is shown in Fig. 2 and Fig. 
3. All columns are rigidly supported at ground. Table 1 shows the 6 load combinations have been considered for the purpose of analysis.

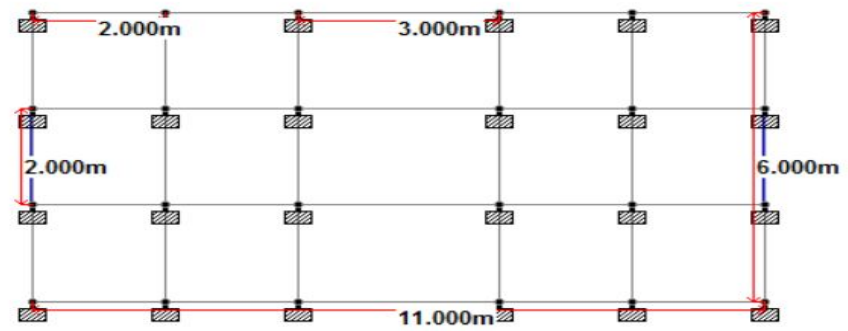

Figure 1. Plan of building

Table -1 Details of load cases

\begin{tabular}{|l|l|}
\hline Load Case No. & Load Case Details \\
\hline 1 & Dead Load \\
\hline 2 & Live Load \\
\hline 3 & WL $_{\mathrm{x}}$ \\
\hline 4 & $1.5 \mathrm{DL}+1.5 \mathrm{LL}$ \\
\hline 5 & $1.5 \mathrm{DL}+1.5 \mathrm{WL}_{\mathrm{x}}$ \\
\hline 6 & $1.2 \mathrm{DL}+1.2 \mathrm{LL}+1.2 \mathrm{WL}_{\mathrm{x}}$ \\
\hline
\end{tabular}

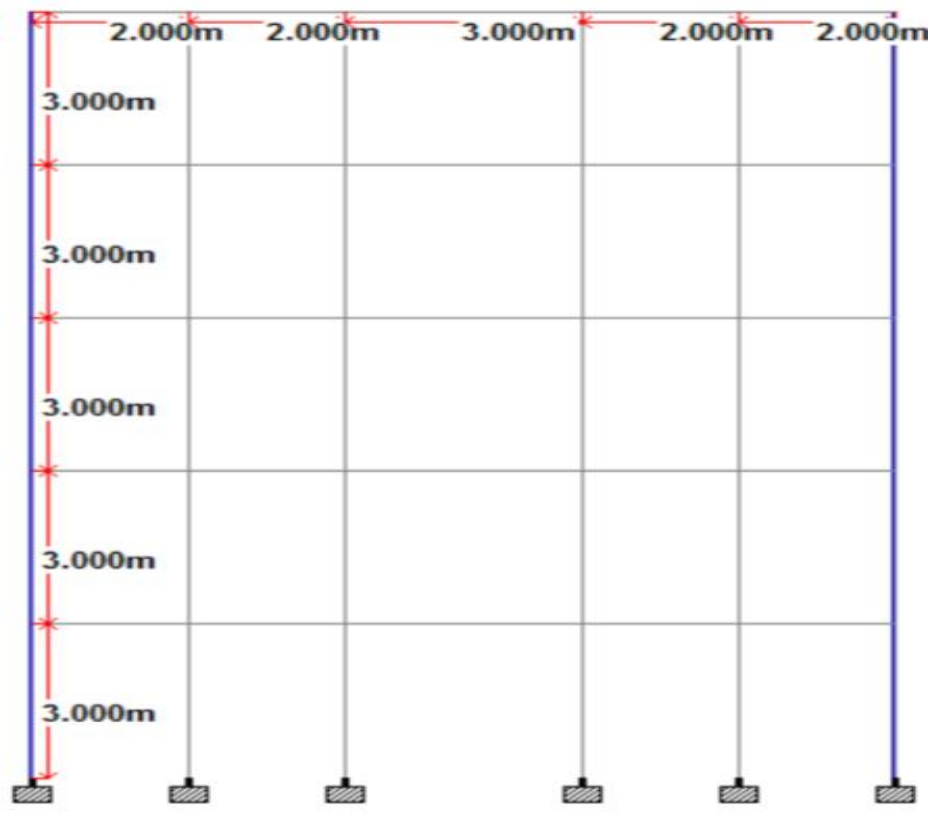

Figure 2. Elevation of building frame 


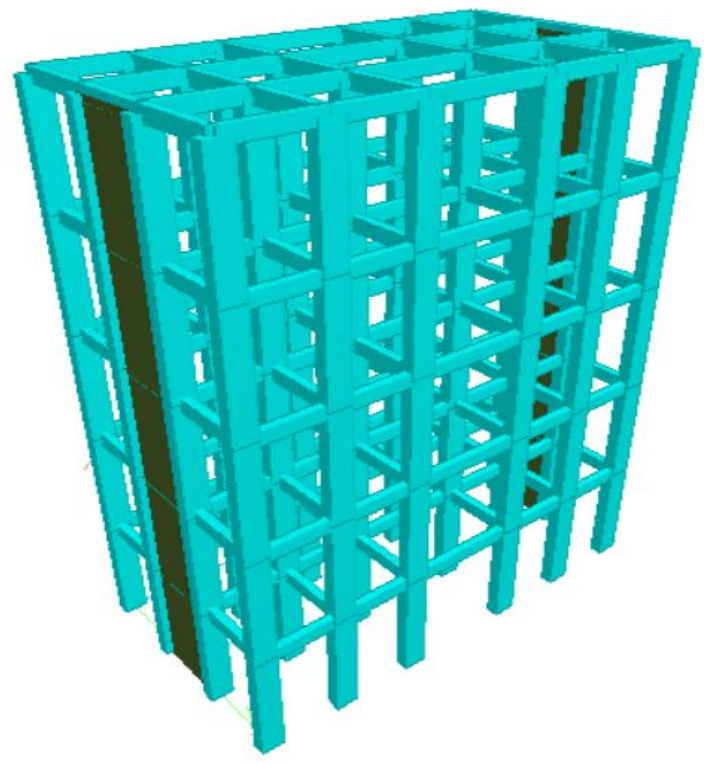

Figure 3. 3D building frame

\section{RESULT AND DISCUSSION}

Results of structural analysis are discussed in following sections. Panel 1 of shear wall is shown in Fig. 4, likewise there are similar rest nine panels, reinforcement details of these, and are same as that of panel 1.The details of reinforcement panel 1 is shown in Table 2, rest nine panels do have same reinforcements. The frame elements i.e. columns and beams do participate in load resistance, quantification of the max. nodal displacement, max. bending moment, maximum shear force, maximum axial force among whole building frame elements is shown in Table 3.

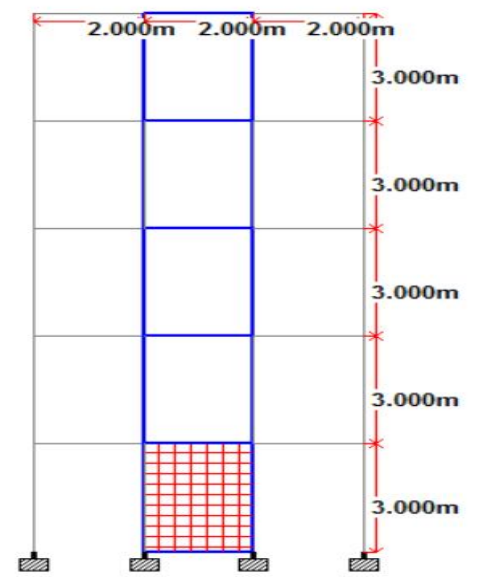

Figure 4. Shear wall on left face (Panel 1 highlighted) 
Table -2 Shear wall panel reinforcement

\begin{tabular}{|l|l|l|l|}
\hline Left Edge & Horizontal & Vertical & Right Edge \\
\hline 5- DIA 8 & 8 DIA @ 100 & 10 DIA @ 300 & 5- DIA 8 \\
\hline
\end{tabular}

Table 3: Values of analysis parameters

\begin{tabular}{|l|l|l|l|}
\hline $\begin{array}{l}\text { Max. Node } \\
\text { disp. } \\
(\text { Res.) }(\mathrm{mm} .)\end{array}$ & $\begin{array}{l}\text { Max. B.M. } \\
\text { Mz (kNm) }\end{array}$ & $\begin{array}{l}\text { Max. Axial Force } \\
\text { Fx }(\mathbf{k N})\end{array}$ & $\begin{array}{l}\text { Max. S.F. } \\
\text { Fy (kN) }\end{array}$ \\
\hline 0.951 & 10.810 & $\mathbf{3 1 8 . 0 9 5}$ & 18.711 \\
\hline
\end{tabular}

Table 4 shows the maximum values of three broadly classified stresses. Stress contours for shear wall are shown in Figure 5, 6, 7. All the three stress contours shows the concentration of stresses in ground and first storey at the left faced shear wall, but the right faced shear wall has stresses slightly above first storey and mid-way level of second storey as evident in Figure 5,6,7.

Table 4: Stresses in Shear wall (N/mm2)

\begin{tabular}{|l|l|}
\hline Max. Absolute & 3.236 \\
\hline Max. Von mises & 3.117 \\
\hline Max. Tresca & 3.236 \\
\hline
\end{tabular}

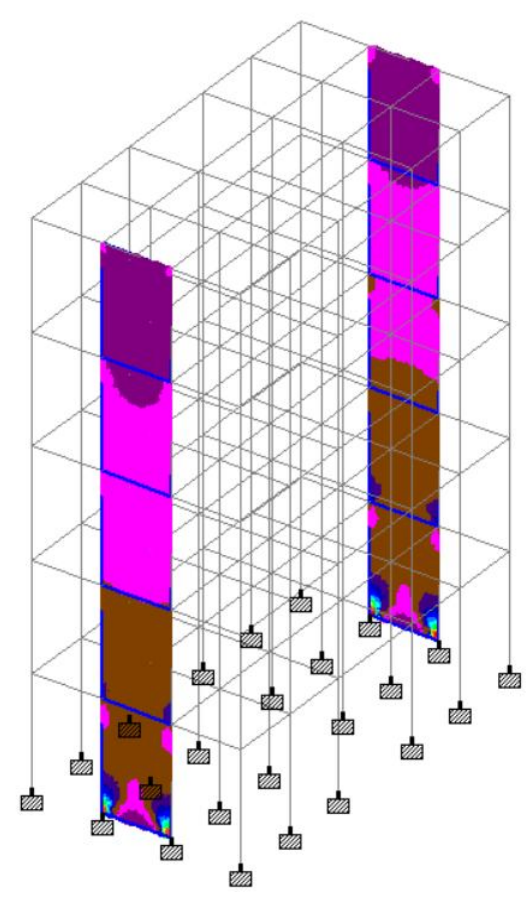

Figure 5. Max. Absolute Stress Contours for shear walls 


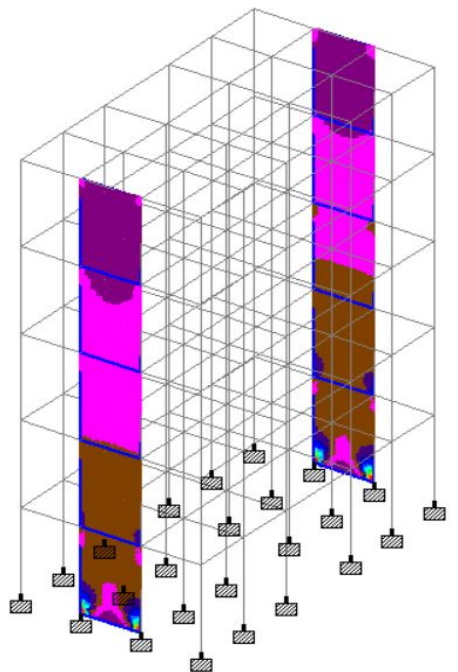

Figure 6. Max. Von Mises Stress Contours for shear walls

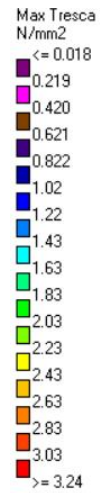

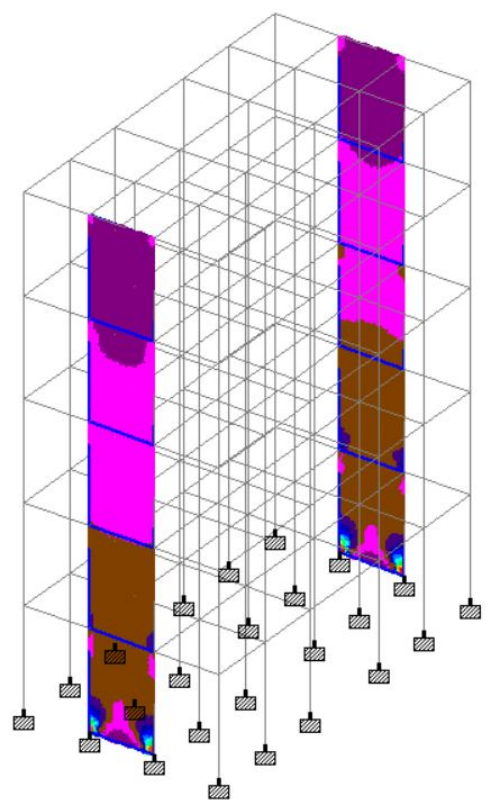

Figure 7. Max. Tresca Stress Contours for shear walls 


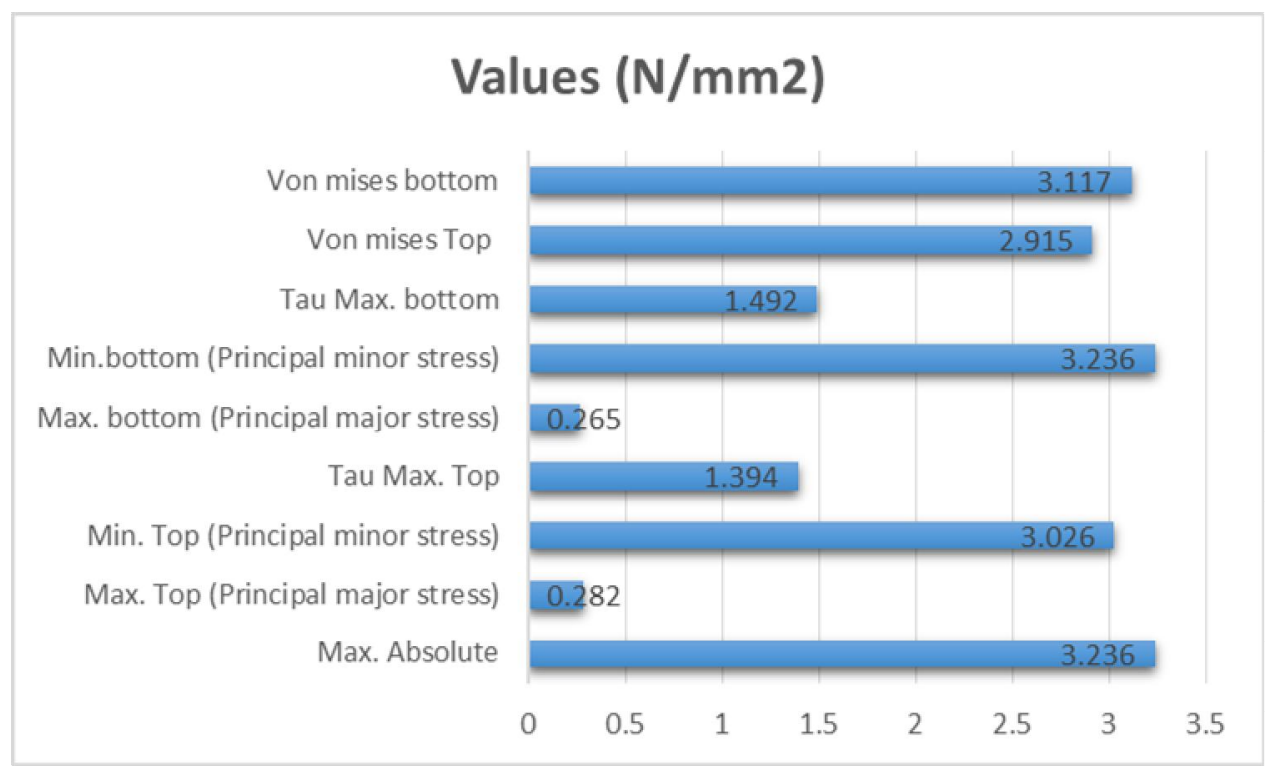

Figure 8. Various stresses in shear walls

Drift is significant in case of building subjected to wind loads. The maximum value of drift at a particular storey is shown in Table 5, whereas the percent-wise depiction of drift is shown in Figure 9.

Table -5 Maximum Storey Drift (mm.)

\begin{tabular}{|l|l|}
\hline Storey & Max. Storey Drift (mm.) \\
\hline Ground & 0.1 \\
\hline First & 0.178 \\
\hline Second & 0.193 \\
\hline Third & 0.173 \\
\hline Fourth & $\mathbf{0 . 1 0 9}$ \\
\hline
\end{tabular}

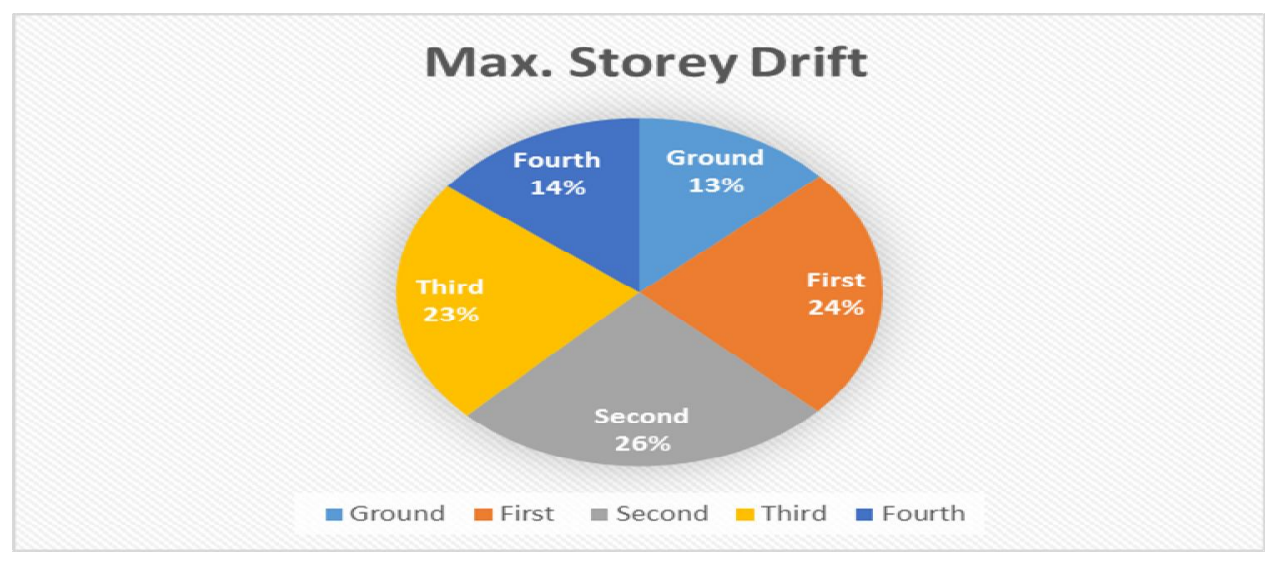

Figure 9. Max. Storey Drift (Percent-wise) 


\section{IV.CONCLUSION}

Following notable conclusions can be drawn with the above conducted analysis and study:

1. The Values of Max. Tresca stresses are found to be decisive as far stress analysis of shear wall is concerned for the above stated building case.

2. Drifting is concentrated at or around mid-height for the building case, despite wind loads being at top storeys.

3. Leeward facing shear wall is stressed higher, particularly at mid-height level, in comparison with the windward facing shear wall as evident from stress contours.

4. A Shear wall designed as per provisions of IS: 456:2000 can be aptly used for buildings with low height, features of shear wall can be enhanced with provision of ductility considerations also.

\section{REFERENCES}

[1] J. Lombard, "Seismic Strengthening And Repair Of Reinforced Concrete Shear Walls", Proc. WCEE, Springer, pp. 207-215, 2004.

[2] A. E. Cardenas, J. M. Hanson, W. G. Corley, and E. Hognestad, "Design Provisions for Shear Walls," Journal of the American Concrete Institute, Proc., pp. 221-230, 1973.

[3] A. Astaneh-Asl, "Seismic Behavior and Design of Steel Shear Walls",Proc. SEOANC Seminar,pp. 1-18, 2001.

[4] H. Hiraishi, " Evaluation of Shear and Flexural Deformations of Flexural Type Shear Walls ", Third South Pacific Regional Conference on Earthquake Engineering, Wellington ,1983. 